\title{
A national turn of local integration policy: multi-level governance dynamics in Denmark and Sweden
}

\author{
Henrik Emilsson
}

\section{Correspondence: henrik.emilsson@mah.se Malmö Institute for Studies of Migration, Diversity and Welfare (MIM), Malmö University, Malmö, Sweden}

\begin{abstract}
There is a growing interest in the research community in the local governance of migration and integration. Studies indicate a local turn in integration policies, with local governments becoming important integration policy actors. Unlike most research, this study of recent developments in the policies for migrant newcomers in Denmark and Sweden observes a national turn in local integration policy. Despite their different integration policies, the central governments of both countries have increased their control and influence at the local level and thereby made it more difficult for local governments to formulate their own integration policies. This study highlights the need to complement earlier research based on frame analysis with an analytical framework that takes central government steering and the uneven power relationship between the levels of government into account.
\end{abstract}

Keywords: Local integration policy; Multi-level governance; Integration policy; Sweden; Denmark; National integration models

\section{Analyzing local integration policy-the setting}

There is a growing interest in the research community in the local aspects of integration and migration (Alexander, 2007; Caponio and Borkert, 2010). The local dimension of integration policy is also acknowledged at the European level, where more efforts are being made to promote knowledge exchanges between cities, for example the CLIP project and the EuroCities network. Criticism of methodological nationalism (Wimmer and Glick-Schiller, 2003) seems to have fuelled a desire to go beyond an analysis of integration policies at the national level. Instead of studying national models of integration, the focus has been on understanding whether and how national policies are implemented at the local level and whether municipalities are formulating policies of their own. Most of these studies indicate a local turn of integration policy and that local governments have increased their significance as integration policy actors (Alexander, 2007; Penninx, Kraal, Martiniello and Vertovec, 2004; Penninx, 2009; Caponio and Borkert, 2010; Schmidtke, 2014). Many of the studies of local integration policies have a multi-level governance perspective. Their main focus is on the relations between national and local integration policies, especially the congruencies and incongruences between local and national policies and between local policies in different cities (Borkert and Bosswick, 2007; Poppelaars and Scholten, 2008; Bak Jørgensen, 2012; 
Scholten, 2013; Dekker, Emilsson, Krieger and Scholten, 2015). While some studies find that national models of integration are still highly influential at the local level, and that there is a congruence between national and local integration policies (Dekker, et al. 2015), most research indicates a growing incongruence between the national and local level (Bak Jørgensen, 2012; Scholten, 2013). There are two main explanations for these incongruences. The local pragmatism thesis argues that there is a specific local dimension of integration policies characterized by a greater tendency to accommodate ethnic diversity and solve integration problems in pragmatic ways (Caponio and Borkert, 2010; Poppelaars and Scholten, 2008; Bak Jørgensen, 2012). The localist thesis argues that there are no national or local models of integration, but that local policies are uniquely shaped by the specific problem-, political- and policy settings in the different cities (Alexander, 2007; Mahnig, 2004). Both the local pragmatist thesis and the localist thesis suggest a disintegration of national integration models and point to the importance of studying integration policy beyond national frameworks.

The fieldwork and research undertaken for the EU-7 framework project, UniteEurope in Copenhagen and Malmö, ${ }^{1}$ made me question the growing consensus on the increased importance of the local level in integration policies. I therefore decided to look for a methodological and theoretical framework that would facilitate an analysis of the recent developments in Denmark and Sweden. The aim of this article is to add a new approach to the study of local integration policies by looking at the multi-level governance of integration policies through a power perspective lens. Power is operationalized by analysing the autonomy of local governments and their compliance with national policies. Contrary to most research, I argue that what we are witnessing is a national turn on local integration policy, where local integration policies and practices are increasingly governed by the state. Using case studies from Denmark and Sweden, I show that in recent years the governments of the two countries have increased their control and local influence and thereby limited the possibilities for local governments to formulate their own integration policies.

One important explanation as to why most researchers agree on a local turn of integration policy and that national models of integration are becoming weaker is that they look at the relationship between the local and national level using frame analysis (see for example Bak Jørgensen, 2012; Scholten, 2013). This makes them look at integration policy from a rhetorical perspective, i.e. how an actor defines the problems, diagnoses the causes, makes moral judgements and suggests remedies for integration (D'Angelo and Kuypers, 2010). Official policy documents are studied with a view to unveiling the central organizing idea or ideology behind the policies. If local governments are found to adopt official integration policies that are ideologically different from those of the central government, the conclusion is that national models of integration are disintegrating. This divergence of local and national integration policy frames has been identified by Bak Jørgensen, (2012) in the case of Denmark and by Scholten, (2013) in the case of the Netherlands. With regard to Germany, Schmidtke, (2014) finds that the growing divergence is a result of a conscious choice to decentralize public policy responsibilities from the federal to regional and local governments. These studies have contributed to the understanding that local governments can also be integration policymakers. At the same time, they risk giving the wrong impression of what is happening at the national and local level when it comes to integration policy. 
I see two main weaknesses with using policy frames to study the multi-level governance of integration. The first is that policy frames/integration ideologies may not mirror actual integration policies and measures. For example, Dahlström, (2004) has found striking discrepancies in Sweden between integration rhetoric and integration practice. Although the national integration policy frames have changed several times since the adoption of the first immigrant policy in 1968 - from universalism to multiculturalism and back again - the practices and measures have not changed in any major way. A similar phenomenon can be found at the local level, where local integration policies often lack legitimacy and are assigned a subordinate role in the administration (Caponio, 2010:179). The second weakness, and the most important for my argument, is that frame analysis often fails to address the power relationship between national and local governments. As I will show, national governments use steering instruments that to a large extent determine the municipalities' discretion when it comes to local integration policies. If the state decides which integration measures should be implemented at the local level it means that local authorities have little room for manoeuvre. Although I suggest that there is a national turn in local integration policies, it does not mean that local dimensions of integration policies do not exist, or that the scholars using frame analysis are wrong in their conclusions that there is a policy divergence between national and local levels of government. Integration policies that go against the national models can be formulated at local level, but may be limited in scope.

The aim of the article is to study whether there is a local or national turn in local integration policies and how this has come about. The cases studied are Denmark and Sweden: two countries with similar welfare states and local government structures (Sellers and Lindtsröm, 2007) but with very different national integration policies (Brochmann and Hagelund, 2012). The stipulation of a national turn is put to the test using these two cases. Denmark and Sweden are two of the most decentralized countries in the world (Sellers and Lindtsröm, 2007) and their migration and integration policies have diverged tremendously over the years of study. If both countries are found to have experienced a national turn of local integration policy the study will have made a valuable contribution to research, especially as in many ways they represent least likely cases.

As will be shown, both national governments have increased their control and local influence and thereby limited the possibilities for local governments to formulate their own integration policies. The centralization of local integration policies has occurred in both cases, albeit in a different way and using different strategies. The increased interference of the national governments in local integration policies takes the form of laws and regulations that force local municipalities to implement certain integration measures by means of increased state funding for measures implemented at the local level and increased direct state involvement in the implementation of local integration policies. Last but not least, in Denmark, state legislation has had an increasing impact on the lives of individual migrants.

Even though this article only investigates the developments in Denmark and Sweden, there are signs of a broader European trend towards a national turn of local integration policy. Other countries have also centralized their integration policies. For example, Germany introduced a national integration policy in 2005 and state agencies are now responsible for integration programmes at the local level. In the last 15 years, many European countries have also introduced civic integration policies that have substantially increased the integration requirements for migrant newcomers (Wallace Goodman, 2010). 
There is not enough space in this article to analyze and discuss how the multi-level relationship between central and local governments is played out in all the different dimensions of integration. In this article, the focus is on local integration policies for migrant newcomers, because this has been one of the most contested integration topics in recent years in both Denmark and Sweden. Newcomer integration is also a topic on which states and cities tend to diverge in perspective and approach (Gebhardt, 2014:3). In the concluding section of the article I sketch a model that demonstrates how the theoretical framework used in this article can be utilized to examine the multi-level governance of integration in a more comprehensive way in future research.

\section{Framework for analyzing local integration policy and multi-level governance}

As indicated at the beginning of the article, most studies of multi-level governance and local integration policy use frame analysis and have focused on the narratives and philosophies of integration and how they differ at the local and national level. I argue that this method only captures one side of the multi-level relationship. In this article I use a method that captures the power relation between the national and local government levels, which in turn determines the discretion at local level when it comes to integration policy. The development of multi-level governance is often described as a result of three broad developmental trends: up, down and out (Pierre and Peters, 2000), or as combining a vertical and horizontal dimension of multi-level governance (Hooghe and Marks, 2003). In this article I am only interested in the relation between the state and the local level/municipalities. In the literature it has been noted that responsibility for certain policy areas has shifted downwards to the regional and local political levels (Hooghe and Marks, 2001) and that governments have replaced traditional forms of governing with governance. The question is whether this is true for integration policies.

I analyze the multi-level governance of integration using a theoretical model inspired by Etzioni, (1975), which was originally developed to make a comparative analysis of complex organizations. The model's main advantage is that it captures the power relations between those higher and lower in rank (ibid. p.5). The central concept in Etzioni's book is compliance, which he sees as a key element in all organizations. Compliance relations are asymmetric and vertical. It is about how subordinated actors behave in relation to another actor's power, and how those in power make other actors follow their directives. As Etzioni points out, a compliance relationship does not assume that the subordinates have no power, only that they have less (Etzioni, 1975, p.4). Etzioni mainly uses his model to understand power relations between people within an organization, although his model has also been used to study how the state governs its authorities and local governments (Vedung, 1991). The relationship we are interested in here is that between the state and local governments. They are part of a common organization, and while local governments have more or less power depending on their national settings, they are always subordinate to central government.

The superior actor, in this case national governments, uses power to ensure the compliance of other actors to carry out the directives and norms it supports. Etzioni describes three instruments of power: coercive, remunerative and normative (ibid, p.5). In the case of states and local governments, it is probably better to use the terms coercive, economic and normative. The instruments can also be seen as sticks, carrots and persuasion. The strength of Etzioni's model is that it captures the multiple ways in which a 
central government can exercise power on local governments that goes beyond a traditional understanding of decentralization and centralization of fiscal resources and formal responsibilities. Thus, it captures a steering that is associated with both governance and government (Kjær, 2004). An alternative theoretical model that could have been used to analyze the central and local government relations is that created by Goldsmith, (2002), although his central concept is control and does not take all of the economic and normative instruments of central government into account.

The methodology of the article is straightforward. In order to study the developments between the local and central governments I mapped all the major policy decisions relating to migrant newcomers according to the three instruments of power (see sections The Swedish case and The Danish case). In the main, secondary literature was used to identify the relevant government documents and legislation that would facilitate an indepth study of the decisions taken.

Coercive instruments can be the laws and regulations imposed by the state through decisions in parliament or, in some cases, decided by central governmental agencies. The municipalities are obliged to act in accordance with these. The relationship between central and local government is in this case authoritative. Reallocations of authority between territorial levels can also be made if the state changes the providers of public services at the different levels of government (Porter and Olsen, 1976). Economic instruments often take the form of state funding or the withdrawal of state funding for targeted measures at the local level implemented by local governments or nongovernmental organizations. Normative instruments involve attempts or the discontinuation of attempts to influence local governments by conviction, persuasion or knowledge. Direct verbal counselling, education and outreach activities are included here. These instruments are not mutually exclusive, but can be combined to enforce compliance at the local level. For example, if the state wants to introduce language tuition for migrants at the local level it can use coercive means through laws and regulations, economic means by providing funding or try normative means to convince municipalities that this is the right thing to do. Alternatively, the state may decide to change its strategy on language tuition, withdraw funding and pass decisions about policy choices to the local level.

In the next part of the article I look at the recent development of integration policies in Sweden and Denmark using the theoretical multi-level governance model described above.

\section{Two faces of centralization of integration policies}

This chapter begins with a brief explanation of the Danish and Swedish government system in order to understand the formal relationships between the local and national level. This is followed by two sections on the development of local integration policies for migrant newcomers in Denmark and Sweden.

\section{Governmental structure in Sweden and Denmark}

Local governments in Sweden and Denmark balance between self-government and central control and between the autonomous and integrational model of local government (Kjellberg, 1995). According to the autonomous model, local governments are a separate 
sphere of government with a primary function to secure democratic participation and the efficient provision of local services. In the integrational model, local governments are one part of the public sector and their main role is to implement national policies. These tensions are evident in the Swedish and Danish integration policies, where the ambitions of the unitary state governments meet powerful local governments (Sellers and Lindtsröm, 2007).

Swedish municipalities are regulated by the Local Government Act of 1991. The Act specifies the responsibilities of the municipalities and provides outlines for local government. According to the law, municipalities are responsible for childcare and for preschool, primary and secondary schools, the social services, care for the elderly, support for people with disabilities, health and environmental issues, emergency services (not policing, which is the responsibility of the central government), urban planning and sanitation (waste, sewage). Labour market policy is a state responsibility, although at the beginning of the 1990s local authorities became increasingly important actors in labour market policy measures at the local level.

In Sweden the public sector is made up of three levels: national, regional and local. The system consists of a centralized national government and municipalities that are to some degree autonomous and have far-reaching powers of their own. The central government exercises power at all three levels, which leads to a relatively complex structure at the local level. There are also regional municipalities, which are mainly responsible for health care and transportation in the region. The municipalities therefore share both power and responsibility with national and regional institutions at the local level.

The principles for local self-government are stated in the constitution. Local and regional municipalities have the right to levy taxes and determine tax rates. The central government has the overall responsibility for determining how resources are to be distributed within the country and directs local activities by providing economic guidelines and establishing framework legislation. One of the goals of central government is to guarantee a minimum standard in relation to the various types of service provided by the municipalities (Gustafsson and Svensson, 1999). Although the national government sometimes decides what municipalities should and must do, they nevertheless have something of a free rein. As we shall see, framework legislation and attempts to guarantee equal access to services for migrants have been important aspects of the development of integration policy in Sweden.

In Sweden there have been trends towards centralization and decentralization in the last decades. In some cases, the state has decentralized responsibilities from regional state administrations to regional governments. At the same time, the central government has passed several laws that restrict the power of local governments. According to Feltenius, (2007), this development is explained by a renewed importance of the principle of equality in welfare provisions.

In Denmark there has been a clearer trend towards decentralization. The major municipal reform of 2007 transferred power to the municipalities. Responsibility for primary education, the social services, care for the elderly, physical planning and child care was retained and in some cases expanded. Municipalities were also given increased responsibility for education, the social services, rehabilitation (outside hospitals) and health promotion. The reform was completed in 2009 when labour market services were decentralized to the municipalities (Blom-Hansen, 2012). Today the municipalities 
alone provide services to the public sector in Denmark (Vrangbk, 2010). These changes also meant a potential increased autonomy in the field of integration policy.

The municipalities and the regions are allowed to take responsibility for areas as long as they do not clash with the responsibilities of the national government or another municipality/region. Most local government functions are carried out with full discretion, apart from some social security benefits (old age pensions in particular) where central government covers part of the costs. The recent reform has strengthened the level of municipal autonomy and made the country even more decentralized than before. Municipalities are entrusted with more fiscal, political and administrative autonomy than in any other country (Ivanyna and Shah, 2012). At the same time as the municipalities' powers were enhanced the regions became less important, with fewer responsibilities and no power to tax their citizens. There is no system of subordination between the regions and the municipalities because they have different tasks and responsibilities. Therefore, the public sector in Denmark only has two levels of governing institutions.

\section{The Swedish case}

Sweden has had a comprehensive immigrant policy in place since 1975 (Bill 1975:26), when a multiculturalist policy was agreed by parliament. Even though many changes in content and terminology have been made since then, the basic framework still applies, which is that migrants should have the same living standards as the native population. Migrants with residence permits therefore have the same rights as Swedish citizens and are covered by the welfare state. Several policies have been introduced: mother-tongue instruction in schools for migrant children, voting rights for foreign citizens in local elections and subsidies for immigrant associations. After 1985 there was a move away from multicultural policy for cultural and economic reasons (Schierup and Ålund, 2011; Geddes, 2003; Södergran, 2000) and 'immigrant and minority policy' was renamed 'immigrant policy' as a result. Following the reorientation in the 1980s the state remained the guarantor of immigrants' social and political rights but not of their minority cultural rights. As the number of humanitarian migrants gradually increased, responsibility for integration was transferred from the Employment Service to the municipalities (Prop. 1983/ 84:125). This shift of responsibility was part of a larger reform aimed at decentralizing integration policies to the municipalities. At the same time, the most important part of Swedish integration policy, namely the introduction programme for humanitarian migrants, was introduced. This is the topic in focus for the remainder of the analysis.

Since decentralization in 1985, the central government has gradually increased its efforts to influence local integration policies for migrant newcomers (see Table 1 for a summary). One reason for the decentralization of the introduction programmes was that the state wanted to introduce individually designed introduction programmes that also took the different local conditions into consideration (Sarstrand Marekovic, 2012). Municipalities were supposed to offer services such as language training, civic orientation and labour market activities and the state would provide the funding. In many municipalities the migrants' social needs were prioritized (Soininen, 1992). The local introduction programmes were often planned and implemented by social workers in line with the Social Services Act. After some time the state reacted to the "care" focus of the programmes and insisted on a stronger focus on labour market integration. 
Table 1 Policies for newly arrived migrants—Sweden

\begin{tabular}{|c|c|c|c|}
\hline Year & Content & Instrument & Political intention \\
\hline $\begin{array}{l}1985 \\
\text { (Bill 1983/84:125) }\end{array}$ & $\begin{array}{l}\text { Responsibility for } \\
\text { introduction programmes } \\
\text { is transferred to } \\
\text { municipalities. }\end{array}$ & $\begin{array}{l}\text { Economic compensation } \\
\text { from the state to } \\
\text { municipalities. }\end{array}$ & $\begin{array}{l}\text { Adaptation of introduction } \\
\text { programmes to local } \\
\text { conditions. }\end{array}$ \\
\hline $\begin{array}{l}1991 \\
\text { (Bill 1989/90:105 and } \\
\text { Ordinance 1990:927) }\end{array}$ & $\begin{array}{l}\text { New system of } \\
\text { reimbursement to } \\
\text { municipalities for refugee } \\
\text { reception. Expansion of } \\
\text { the target group. }\end{array}$ & $\begin{array}{l}\text { Increased economic } \\
\text { incentives for municipalities. }\end{array}$ & $\begin{array}{l}\text { In collaboration with the } \\
\text { Employment Service give } \\
\text { local governments the } \\
\text { freedom to take active } \\
\text { measures to enable migrants } \\
\text { to become self-sufficient. }\end{array}$ \\
\hline 1992 (Bill 1992:1068) & $\begin{array}{l}\text { New introductory benefits } \\
\text { for refugees and other } \\
\text { foreigners. }\end{array}$ & $\begin{array}{l}\text { Increased economic } \\
\text { incentives for participants in } \\
\text { introduction programmes. }\end{array}$ & $\begin{array}{l}\text { Municipalities are given the } \\
\text { chance to use non-means } \\
\text { tested economic support to } \\
\text { participants in an introduction } \\
\text { programme. }\end{array}$ \\
\hline $\begin{array}{l}1998 \\
\text { (Bill 1997/98:16) }\end{array}$ & $\begin{array}{l}\text { New integration policy and } \\
\text { establishment of the } \\
\text { Integration Board. }\end{array}$ & $\begin{array}{l}\text { Increased normative } \\
\text { instruments for } \\
\text { implementation of } \\
\text { introduction programmes. }\end{array}$ & $\begin{array}{l}\text { The new agency is to help } \\
\text { municipalities to improve } \\
\text { support for new immigrants. }\end{array}$ \\
\hline 2001 & $\begin{array}{l}\text { Central, regional and local } \\
\text { agreements. }\end{array}$ & $\begin{array}{l}\text { Increased normative } \\
\text { instruments. }\end{array}$ & $\begin{array}{l}\text { Strategy to improve } \\
\text { collaboration and improve } \\
\text { coordination of introduction } \\
\text { programmes. }\end{array}$ \\
\hline $\begin{array}{l}2010 \\
\text { (Bill 2009/10:188) }\end{array}$ & $\begin{array}{l}\text { National Bonus for } \\
\text { language acquisition }\end{array}$ & $\begin{array}{l}\text { Increased economic } \\
\text { incentives for participants in } \\
\text { language tuition. }\end{array}$ & $\begin{array}{l}\text { Encourage new immigrants } \\
\text { to learn Swedish faster. }\end{array}$ \\
\hline $\begin{array}{l}2010 \\
\text { (Bill 2009/10:60) }\end{array}$ & $\begin{array}{l}\text { Responsibility for } \\
\text { introduction programmes } \\
\text { is transferred to the state. }\end{array}$ & $\begin{array}{l}\text { Coercive instruments } \\
\text { towards municipalities. } \\
\text { Increased economic } \\
\text { incentives for participants in } \\
\text { introduction programmes } \\
\text { and private actors. }\end{array}$ & $\begin{array}{l}\text { Speed up new migrants' } \\
\text { transfer into work. }\end{array}$ \\
\hline $\begin{array}{l}2014 \\
\text { (Bill 2012/13:188) }\end{array}$ & $\begin{array}{l}\text { Expansion of the target } \\
\text { group. }\end{array}$ & $\begin{array}{l}\text { Economic compensation } \\
\text { from the state to } \\
\text { municipalities }\end{array}$ & $\begin{array}{l}\text { Give more family-reunification } \\
\text { migrants right to an } \\
\text { introduction programme. }\end{array}$ \\
\hline
\end{tabular}

In 1991 the state decided on a new system of reimbursement to municipalities for refugee reception (Bill 1989/90:105 and Ordinance 1990:927). The purpose of the changes was to increase the incentives for municipalities to speed up the labour market integration. Previously, the state had compensated the municipalities' costs for social assistance. Now, municipalities were given a lump sum compensation for each person. This meant that local governments could keep the state money if the newcomers became self-sufficient at a faster rate than the 2 years covered by state funding. At this time the only coercive regulatory framework for the receipt of state funding was that an introduction plan had to be drawn up for each individual. One year later, in 1992, another economic incentive was introduced (Bill 1992:1068) which allowed municipalities to give non-means tested economic support to participants in an introduction programme and thereby increase their economic incentives to find employment.

The 1997 integration policy (Bill 1997/98:16) emphasized individual rights and mainstreaming, but did little to change existing integration measures. The regulatory framework for the local introduction programmes was also retained. In order to encourage municipalities to adopt more efficient introduction programmes with a stronger focus 
on employment, the state now turned to normative steering measures (Qvist, 2012). A new state agency, the Swedish Integration Board, was set up. One of its main tasks was to stimulate and help municipalities to develop better and more efficient introduction programmes. The idea at that time was to design an individual introduction with a focus on work that, as far as possible, mimicked working life with activities amounting to a standard working week of 40 hours. The initial strategy of the agency was to provide local governments with knowledge, highlight good examples and write follow-up reports. When this strategy was seen as insufficient to influence policy change, the Swedish Integration Board initiated a strategy for the collaboration and coordination of integration programmes. It tried to increase policy coordination by means of different types of agreements between involved stakeholders at the national, regional and local level. This strategy was successful and produced local and regional agreements on work-first policy. However, according to Qvist, (2012), this did not really lead to corresponding changes in the organization and structure of the local programmes.

Despite these efforts the central government was not happy about the efficiency of the programmes. The Social Democrat Government therefore appointed a Commission of Inquiry to suggest improvements. The proposals (SOU 2003:75) presented in 2003 would have meant a certain centralization of the introduction programmes, but the government failed to reach agreement with its coalition partners and the reform was abandoned. After the 2006 elections, and with a new centre-right government in place, the Swedish Integration Board was laid down. As the economic and normative steering instruments that had been tried had not yielded results, the government now introduced coercive methods. With the 2010 reform (Bill 2009/10:60) the state took over responsibility for the introduction programmes from the municipalities. According to the government, the old programmes had too little focus on labour market activities and resulted in slow labour market integration. Giving the Employment Service overall responsibility supposed to strengthen the work-first principle. The government also believed that the differences between how municipalities organized the programmes were too great and felt that centralization would guarantee a better implementation of state policy. The government also launched an introduction benefit for participants in the programme; an individual state allowance that replaced the old municipal social benefits. Despite the reform the need for local coordination remained great. Today, municipalities are still responsible for Swedish for Immigrants (SFI) and civic orientation courses, for which they receive state funding. A new private actor, an introduction guide, was also introduced to help migrants find employment, which further added to the need for coordination. The reform meant increased state involvement in three ways: the responsibility and administration for the introduction programmes moved from the municipalities to the state, state funding for the programme increased and the content of the programme became regulated by law.

The introduction reform has contributed to the greater centralization of integration policy for migrant newcomers in Sweden, although is not the only example of this. The state, which in Sweden is responsible for labour market policy, has introduced subsidized employment directed at migrant newcomers. The state budget for the local introduction programmes has sky-rocketed from about five billion SEK a year in 2006-2011 to 13 billion in 2014, and is expected to reach 25 billion in 2017. This is due to a rising number of humanitarian migrants in combination with increased spending per person. In addition, the 
target group for the introduction programmes expanded in January 2014 (Bill 2012/ 13:188). Family members of humanitarian migrants arriving in Sweden within a 6 years period, instead of 2 years, are now eligible for an introduction programme. Other state centralization efforts affecting the local level are a new law that forces municipalities to accept the settlement of unaccompanied minors, increased rights for undocumented migrants and state funding for local anti-discrimination measures.

\section{The Danish case}

Danish immigrant policy was progressively developed in the 1970s by reforms in different policy areas. The main principle was equal rights in the welfare state with a few targeted measures, such as language training for migrant newcomers and mother-tongue instruction in schools (Vad Jönsson and Petersen, 2012). When refugees began to arrive in larger numbers in the 1980s the government gave the NGO Danish Refugee Council responsibility for humanitarian migrant newcomers. Introduction activities were mainly carried out by the Danish Refugee Council, which was authorized to grant social benefits to participants. In 1986 Denmark introduced an 18-month long integration programme for humanitarian migrants. This programme included language training and civic orientation, but no labour market activities to speak of. After this period responsibility was handed over to the municipalities.

Just as in Sweden, in the last decade the Danish central government has decided on policies and legislation that have increased its influence on integration measures at the local level. This has not only had profound consequences for municipalities, but also for individual migrants (see Table 2 for a summary). The process started in 1994 when the Integration Action Plan made the municipalities responsible for language training for all migrant newcomers.

The 1998 Integration Act (Act no. 474 of 1 July 1998) made the municipalities responsible for carrying out the integration policy objectives (Jensen, Schmidt, Tørslev, Vitus and Weibell, 2010), primarily the introduction programme that was now expanded to include all non-EEA migrants. The aim was to improve the management and coordination of the integration programmes by assembling all the separate elements under the same political authority. The Act also stated labour market integration as an explicit goal for the first time. Municipalities are thus obliged to offer 3-year introduction programmes in which language training is the key pillar. Also, since 1999 it is up to the state to decide where humanitarian migrants should settle by assigning local and regional quotas (Nielsen and Jensen 2006). In other words, the municipalities are responsible for the introduction programmes and their tasks are clearly stated in the Act. Vad Jönsson and Petersen (2012) describe the policy change as a public centralistic welfare state solution. Djuve and Kavli, (2007) categorize the introduction regime as a detailed law regulation. The cost of benefits and services are reimbursed by the state. The reimbursement system is quite complicated and different procedures have been used to encourage municipalities to implement efficient programmes. Since 2007 economic compensation to municipalities has consisted of three parts, one of which depends on the results of language training and labour market entry.

When several steps were taken to restrict the migration of non-EU citizens to the country the number of humanitarian and family migrants fell, while the number of other migrant categories rose. As a response to this, the Danish Government decided in 2010 to 
Table 2 Policies for newly arrived migrants-Denmark

\begin{tabular}{|c|c|c|c|}
\hline Year & Content & Instrument & Intention \\
\hline $\begin{array}{l}1994 \text { Integration } \\
\text { action plan }\end{array}$ & $\begin{array}{l}\text { Responsibility for language } \\
\text { training transferred to } \\
\text { municipalities }\end{array}$ & & \\
\hline $\begin{array}{l}1999 \text { (Act no. } 474 \\
\text { of } 1 \text { July 1998) }\end{array}$ & $\begin{array}{l}\text { Responsibility for } \\
\text { introduction programmes is } \\
\text { transferred to municipalities. }\end{array}$ & $\begin{array}{l}\text { Economic and coercive } \\
\text { instruments were introduced } \\
\text { directed at both municipalities } \\
\text { and participants in } \\
\text { introduction programmes. }\end{array}$ & $\begin{array}{l}\text { Make newly-arrived refugees } \\
\text { and immigrants active } \\
\text { participants, self-supporting } \\
\text { and with an understanding } \\
\text { of Danish fundamental } \\
\text { values and norms. }\end{array}$ \\
\hline $\begin{array}{l}2002 \text { (Act no. } 364 \\
\text { and no. } 365 \text { of } 6 \\
\text { June 2002) }\end{array}$ & $\begin{array}{l}\text { Integration requirements } \\
\text { were introduced for } \\
\text { obtaining permanent } \\
\text { residence permits. }\end{array}$ & $\begin{array}{l}\text { Economic and coercive } \\
\text { instruments directed at } \\
\text { participants in introduction } \\
\text { programmes. }\end{array}$ & $\begin{array}{l}\text { Migrants have a duty to } \\
\text { participate actively in the } \\
\text { different programme } \\
\text { elements. }\end{array}$ \\
\hline $\begin{array}{l}2006 \text { (Act no. } 243 \\
\text { of } 27 \text { March 2006) }\end{array}$ & $\begin{array}{l}\text { Migrants must sign an } \\
\text { integration contract. }\end{array}$ & $\begin{array}{l}\text { Normative instruments } \\
\text { directed at participants in } \\
\text { introduction programmes. }\end{array}$ & $\begin{array}{l}\text { Making Danish values more } \\
\text { visible. }\end{array}$ \\
\hline $\begin{array}{l}2007 \text { (Act no. } 379 \\
\text { of } 25 \text { April 2007) }\end{array}$ & $\begin{array}{l}\text { Immigration test for family } \\
\text { migrants is introduced }\end{array}$ & $\begin{array}{l}\text { Coercive instruments directed } \\
\text { at family migrants }\end{array}$ & $\begin{array}{l}\text { Foreigners are to receive } \\
\text { clear signals about what is } \\
\text { expected of them in } \\
\text { Denmark. }\end{array}$ \\
\hline $\begin{array}{l}2010 \text { (Act no. } 571 \\
\text { of } 31 \text { May 2010) }\end{array}$ & $\begin{array}{l}\text { The Integration Act was } \\
\text { extended to include labour } \\
\text { migrants and their families } \\
\text { plus EU migrants. }\end{array}$ & $\begin{array}{l}\text { Coercive instrument directed } \\
\text { at municipalities. }\end{array}$ & $\begin{array}{l}\text { Adjust the Act to a changed } \\
\text { migration pattern. }\end{array}$ \\
\hline $\begin{array}{l}2010 \text { (Act no. } 572 \\
\text { of } 31 \text { May 2010). }\end{array}$ & $\begin{array}{l}\text { New point based system } \\
\text { making it harder to obtain } \\
\text { permanent residence permit. }\end{array}$ & $\begin{array}{l}\text { Coercive instruments directed } \\
\text { at participants in introduction } \\
\text { programmes. }\end{array}$ & $\begin{array}{l}\text { Favour well-integrated while } \\
\text { making it harder for "less } \\
\text { integrated" migrants. }\end{array}$ \\
\hline
\end{tabular}

include other migrant categories in the Integration Act (Ersbøll and Gravesen, 2010). For the municipalities this means that they now are obliged by law to offer a larger number of migrants an introduction course.

Due to the fact that coercive instruments were introduced at an earlier stage in Denmark to ensure compliance at the local level, normative instruments have not been used as extensively as in Sweden. The main normative instrument has been the benchmarking system for measuring municipalities' success in the labour market integration of migrant newcomers set up in 2002 (Liebig, 2007) to compare the diffusion of effective integration measures between municipalities.

Compared to Sweden, the Danish state authorities are not involved in the implementation of the introduction programmes. However, municipalities must offer integration services to a broader target group, for which they receive state funding. We can thereby conclude that over time the state has increased its use of coercive and economic instruments to ensure compliance with national policies, which in turn has reduced the possibilities for municipalities to independently decide on integration policies for migrant newcomers.

The other aspect of the centralization of Danish integration policy is how the national integration policies affects individual migrant newcomers. This perspective of the debate on the local turn has been neglected. Most European countries have introduced some kind of forced integration in their migration and integration legislation, where migrants have to show a willingness and capacity to integrate in order to stay in the country and have equal rights (Wallace Goodman, 2010). This type of legislation prevents municipalities from developing an independent local integration policy. In the Danish case, all the 
municipalities can do is administer the rules and procedures and advise migrant newcomers on the best way forward.

Besides the 1998 Integration Act (Act no. 474 of 1 July 1998) meaning less discretion for municipalities, it also signalled the start of one of the most restrictive and controlling integration regimes in Europe (see for example Mouritsen, Lex, Lindekilde and Olsen, 2009 and Ersbøll and Gravesen, 2010). The Act introduced various integration requirements for obtaining a permanent residence permit. Now humanitarian migrants had to show 'a will to integrate' by participation in a 3-year integration programme. At the same time, the government introduced significantly lower welfare payments to humanitarian migrants (the so-called introduction benefit). Its official rationale was to increase the incentive to provide for oneself, although the lower benefit was also designed to prevent individuals from seeking asylum in Denmark in the first instance (Mouritsen, et al. 2009). When a centre-right government took office with support from the Danish People's Party in autumn 2001, the path towards the restriction of immigration and the introduction of integration requirements was vigorously pursued. The requirements for obtaining a permanent residence permit and citizenship became tighter. Danish language tests and employment requirements were also introduced in order to qualify for permanent residence, family reunification and naturalization. The right to family reunification was also removed for everyone below the age 25 .

More legislation on integration requirements followed in 2006 and 2007 with the introduction of an integration contract and integration examination. These changes meant that the stakes for obtaining a permanent residence permit were raised. The required language level for permanent residence was increased to D2E, comparable to the European level B1. The applicant is also required to have been in ordinary full-time employment for at least 2 years and 6 months over the past 7 years. The latest major integration related policy changes were made in 2010. A pre-immigration test for foreigners applying for family reunification was introduced with a view to strengthening the individual foreigner's possibilities for a successful and rapid integration into Danish society. Applicants have to take the test in Denmark and are denied residence if they fail.

The integration legislation is based on the idea that 'permanent residence is reserved for foreigners who integrate', that 'results count' and that 'citizenship must be earned' (Ersbøll and Gravesen, 2010). For the individual migrant, the integration process means a one-way compliance with the standards set by the state. Migrants therefore have to jump through several legal hoops and prove that they are economically independent and culturally integrated in order to become a Danish citizen (Howard 2009, Bak Jørgensen, 2012).

To sum up, at the local level municipalities and individual migrants are increasingly governed by the central government. In 1999 the central government passed detailed legislation indicating the kind of introduction services a municipality had to offer nonEEA migrant newcomers. In 2010 the provisions were extended to all migrants. Also, municipalities have no say where humanitarian migrants are settled. For individual migrants, the coercive measures of the state are even more profound.

\section{Concluding discussion}

This article uses Denmark's and Sweden's policies for migrant newcomers as case studies to examine whether or not there has been a local or national turn in local integration policy. The analysis shows that today central governments have more influence 
and control over local integration policies for migrant newcomers than ever before. The developments can be seen as centralization, but could also be seen as a transition from steering through softer instruments (governance) to more traditional command and control instruments (government).

Since the early 1990s, the Danish and Swedish national governments have made considerable efforts to influence local integration policies for migrant newcomers in what is for them regarded as a desired direction. This has been a struggle, since both countries have some of the most decentralized government structures in the industrialized world. Normative, economic and coercive instruments have been used to make local governments comply with the ambitions of the national governments. In Denmark, the world's first integration law was passed in 1999 that provided municipalities with detailed instructions as to kind of introduction programmes they had to implement. Even though the government structure in Denmark was decentralized further in the beginning of the 2000s, local governments have very little autonomy in the integration policies of migrant newcomers. Their task is to implement what is laid down in the national laws. This also includes a large part of the administration compelling individual migrants to comply with the national integration requirements.

In Sweden the central government has been more hesitant about using coercive instruments to make local governments comply with national ambitions. Until 2010 the municipalities were able to decide for themselves what kind of introduction programmes they wanted to develop. The national government tried to steer the programmes towards a more work-line principle by using normative and economic instruments. After disappointing results, the national government decided to take over responsibility by putting the Employment Service in charge of the introduction programmes. In this respect the national government not only stripped the municipality of a large part of its autonomy, but also took control of the implementation procedure.

When Copenhagen, the capital of Denmark, proclaims that it will become the most inclusive city in Europe by 2015, that integration is a two-way process and that diversity is strength (Copenhagen, 2011), it is easy to think that the Danish national model for integration is losing its influence and power. After all, the ambitions of Copenhagen are very different from the assimilation policy of the central government. But local integration policies matter little when central governments use coercive instruments to ensure compliance with national integration policies. A city like Copenhagen may want to break out of the policy frame set by the central government, but when it comes to policies for migrant newcomers, all they can do is decide more about less. The city still has to implement a never ending list of integration measures and administer the integration requirements directed at migrants that are laid down in the Integration Act and other state legislation.

The Copenhagen example shows that it is important to complement the research on local integration policy using frame analysis with research that also looks at the power relations between central and local governments and central governments' use of different instruments of compliance. This article has examined one area of integration policy, namely that directed at migrant newcomers. While most studies of multi-level governance and integration policy have found that local governments are increasing in importance, I have shown that when it comes to migrant newcomers, local integration policy is increasingly governed by national governments. In both the Danish and Swedish cases there has 
been a centralization of authority and disempowerment at the sub-national level. In Sweden, the national government ended up using coercive instruments and took over responsibility for the entire policy area. Municipalities are now subordinate to the state in the development of local introduction programmes. Denmark uses the Integration Act as a coercive instrument to make sure that local governments and migrant newcomers comply with the wishes of the Danish national government.

The findings suggest that national models of integration are still strong and have grown stronger in recent times. Whether this is true in other countries is an open question, as is whether other dimensions and areas of integration have developed in a similar way. In order to improve the knowledge on this topic I suggest a typology for future research that combines Alexander's, (2007) typology of local migration policies with the Etzioni, (1975) framework to analyze the power relations and compliance described in this article. In this way, the multi-level dynamics of local integration policy could be explored more fully.

In Table 3, three different instruments for compliance are listed on the vertical axis, as described in the theoretical framework. The horizontal axis includes the four dimensions of integration policy (Biezeveld and Entzinger, 2003; Alexander, 2007): socio-economic, sociocultural, legal-political and spatial (see also Freeman, 2004; Samers, 2010). The socio-economic dimension captures a broad category of policy areas, such as the labour market, education, housing, healthcare, social security and policing. The socio-cultural dimension captures the more subjective and interactive dimension of migrant integration. This dimension involves policies referring to processes of migrant acculturation. The legal-political dimension primarily captures the civic and political incorporation of migrants into society. The legal part of this refers to access to citizenship, anti-discrimination legislation and legal provisions that are specific to migrant groups. The spatial dimension basically separates out the indicators related to 'housing' from the socio-economic dimension and puts them together in a separate dimension. The spatial dimension refers to the housing position of migrants, as well as the spatial concentration or dispersion of migrants and symbolic spatial uses.

The different boxes in the table show examples of possible state involvement in local integration policy categorized by the instruments of compliance and the dimensions of integration. This article is situated in the socio-economic dimension and analyzes the multi-level relations between the state and municipalities over time in Denmark and Sweden. For a fuller picture of the multi-level dynamics of integration policy, other integration dimensions should also be studied to determine whether we really are experiencing a national or local turn of local integration policy.

Table 3 Typology of state-municipal relations in local integration policy, by compliance instruments and dimensions of integration

\begin{tabular}{|c|c|c|c|c|}
\hline & Socio-economic & Legal-political & Socio-cultural & Spatial \\
\hline Coercive & $\begin{array}{l}\text { Integration Act on introduction } \\
\text { programmes. }\end{array}$ & $\begin{array}{l}\text { Citizenship } \\
\text { legislation. }\end{array}$ & $\begin{array}{l}\text { Regulations of mother- } \\
\text { tongue } \\
\text { classes in schools. }\end{array}$ & $\begin{array}{l}\text { Regulations of } \\
\text { tax-reductions in } \\
\text { disadvantaged } \\
\text { neighbourhoods. }\end{array}$ \\
\hline Economic & $\begin{array}{l}\text { Funding for introduction } \\
\text { programmes. }\end{array}$ & $\begin{array}{l}\text { Funding for local } \\
\text { anti-discrimination } \\
\text { centres. }\end{array}$ & $\begin{array}{l}\text { Funding for civic } \\
\text { orientation education }\end{array}$ & $\begin{array}{l}\text { Funding for anti- } \\
\text { segregation } \\
\text { programmes. }\end{array}$ \\
\hline Normative & $\begin{array}{l}\text { State knowledge-sharing of } \\
\text { good examples of labour mar- } \\
\text { ket activities }\end{array}$ & $\begin{array}{l}\text { State advertisement } \\
\text { for local elections. }\end{array}$ & $\begin{array}{l}\text { State programmes for } \\
\text { religious tolerance in } \\
\text { schools. }\end{array}$ & $\begin{array}{l}\text { Voluntary } \\
\text { agreements on } \\
\text { refugee reception. }\end{array}$ \\
\hline
\end{tabular}




\section{Endnotes}

${ }^{1}$ Some of the research is published in Dekker, et al. (2015).

\section{Competing interests}

The author declare that he has no competing interests.

Received: 6 May 2014 Accepted: 9 March 2015

Published online: 12 August 2015

\section{References}

Alexander, M (2007). Cities and Labour Immigration: Comparing Policy Responses in Amsterdam Paris Rome and Tel Aviv. Aldershot: Ashgate Publishing

Bak Jørgensen, M. (2012). The Diverging Logics of Integration Policy Making at National and City Level. International Migration Review, 46(1), 244-278.

Biezeveld, R, \& Entzinger, H. (2003). Benchmarking in Immigrant Integration. Rotterdam: Report for the European Commission.

Blom-Hansen, J. (2012). Local Government in Denmark and the 2007 Municipal Reform. In A Moisio (Ed.), Rethinking local government: Essays on municipal reform. Helsinki: Vatt Publications.

Borkert, M, \& Bosswick, W (2007). Migration Policy-making in Germany. Between National Reluctance and Local Pragmatism?, IMISCOE Working article 20. Amsterdam: IMISCOE.

Brochmann, G, \& Hagelund, A. (2012). Immigration policy and the Scandinavian welfare state 1945-2010. London: Palgrave Macmillan.

Caponio, T, \& Borkert, M. (2010). The Local Dimension of Migration Policymaking. Amsterdam: Amsterdam University Press.

Copenhagen (2011). Engage in CPH Citizenship + Inclusion, Copenhagen's integration policy 2011-2014. The City of Copenhagen: Employment and Integration Administration.

Dahlström, C. (2004). Nästan välkomna. Invandrarpolitikens retorik och praktik. (Almost Welcome. Rhetoric and Practice in Immigrant Policy). Göteborg Studies in Politics 87. Gäteborgs Universitet.

D’Angelo, P, \& Kuypers, JA. (2010). Doing News Framing Analysis. New York: Routledge.

Dekker, R, Emilsson, H, Krieger, B, \& Scholten, PWA (2015). A Local Dimension of Integration Policies? A Comparative Study of Berlin, Malmö and Rotterdam, International Migration Review. doi:10.1111/imre.12133.

Djuve, AB, \& Kavli, HC. (2007). Integrering i Danmark, Sverige og Norge: Felles utfordringer - like løsninger? [Integration in Denmark, Sweden and Norway: Mutual Challenges - same solutions?], Tema Nord 2007:575. Copenhagen: Nordisk Ministerråd.

Ersbøll, E, \& Gravesen, LK. (2010). Country Report Denmark, The INTEC project: Integration and Naturalisation tests: the new way to European Citizenship. Centre for Migration Law: Radboud University Nijmegen.

Etzioni, A (1975). A comparative analysis of complex organizations: on power, involvement, and their correlates. New York: The Free Press.

Feltenius, D. (2007). Relations Between Central and Local Government in Sweden During the 1990s: Mixed Patterns of Centralization and Decentralization. Regional \& Federal Studies, 17(4), 457-474.

Freeman, GP. (2004). Immigrant incorporation in Western democracies. International Migration Review, 38(3), 945-969.

Gebhardt, D. (2014). Building Inclusive Cities: Challenges in the Multilevel Governance of Immigrant Integration in Europe. DC, Migration Policy Institute: Washington.

Geddes, A. (2003). The Politics of Migration and Immigration in Europe. London: SAGE Publications.

Goldsmith, M. (2002). Central Control over Local Government - A Western European Comparison. Local Government Studies, 28(3), 91-112.

Gustafsson, L, \& Svensson, A (1999). Public Sector Reform in Sweden. Malmö: Liber AB.

Hooghe, L, \& Marks, G. (2001). Multi-level Governance and European Integration. Rowman \& Littlefield cop: Lanham, MD.

Hooghe, L, \& Marks, G. (2003). Unravelling the Central State, but How? Types of Multi-level Governance. American Political Science Review, 97, 233-243.

Howard, MM (2009). The politics of citizenship in Europe. New York: Cambridge University Press.

Ivanyna, M, \& Shah, A. (2012). Policy Research Working Article 6138. The World: Bank. How Close Is Your Government to Its People? Worldwide Indicators on Localization and Decentralization.

Jensen, TG, Schmidt, G, Tørslev, MK, Vitus, K, \& Weibel, K (2010). Analysis of Integration Policies and Public State-Endorsed Institutions at National and Regional Levels in Denmark, Working article produced within the TOLERANCE project, EU-TOLERACE: The Danish National Centre for Social Research.

Kjær, AM. (2004). Governance. Cambridge: Polity Press.

Kjellberg, F. (1995). The Changing Values of Local Government. The ANNALS of the American Academy of Political and Social Science, 540(1), 40-50

Liebig, T (2007). Labour market integration of immigrants in Denmark. OECD Social, employment and migration working articles No.50, Paris: OECD.

Mahnig, H. (2004). The Politics of Minority-Majority Relations: How Immigrant Policies Developed in Paris, Berlin and Zurich. In R Penninx, K Kraal, M Martiniello, \& S Vertovec (Eds.), Citizenship in European Cities (pp. 17-37). Immigrants, Local Politics and Integration Policies, Farnham: Ashgate Publishing.

Mouritsen, P, Lex, S, Lindekilde, L, \& Olsen, V. (2009). Immigration, integration and the politics of cultural diversity in Denmark: Political discourses and legal, political and educational challenges: Integrated country report. Department of political science: University of Aarhus.

Nielsen, CP, \& Jensen, KB. (2006). Integrationslovens betydning for flygtninges bosätning [The impact of the Integration Act on the settlement of refugees]. Köpenhamn: AKF-förlag.

Penninx, R. (2009). Decentralising Integration Policies. Managing Migration in Cities, Regions and Localities, Policy Network Article November. London: Policy Network.

Penninx, R, Kraal, K, Martiniello, M, \& Vertovec, S. (2004). Citizenship in European Cities. Immigrants, Local Politics and Integration Policies. Farnham: Ashgate Publishing. 
Pierre, J, \& Peters, BG. (2000). Governance, Politics and the State. New York: St. Martin's Press.

Poppelaars, C, \& Scholten, P. (2008). Two Worlds Apart. The Divergence of National and Local Immigrant Policies in the Netherlands. Administration \& Society, 40(4), 335-357.

Porter, D. O. \& Olsen, E. A. (1976). Some critical issues in government centralization and decentralization. Public Administration Review, 36(1), 72-84.

Qvist, M (2012). Styrning av lokala integrationsprogram: Institutioner, nätverk och professionella normer inom det svenska flyktingmottagandet [Governing Local Integration Programmes: Institutions, Networks and Professional Norms in Swedish Refugee Reception]. Linköping: Linköpings Universitet.

Samers, M. (2010). Migration. London: Routledge.

Sarstrand Marekovic, AM (2012). Kommunalt mottagande av invandrare och flyktingar - 40 år av utmaningar och erfarenheter [Local integration of immigrants and refugees -40 years of challenges and experiences]. Socialmedicinsk tidskrift 2/2012,

Schierup, C, \& Ålund, A. (2011). The end of Swedish exceptionalism? Citizenship, neoliberalism and the politics of exclusion. Race and Class, 53(1), 45-64.

Schmidtke, O. (2014). Beyond National Models? Governing migration and integration at the regional and local levels in Canada and Germany. Comparative Migration Studies, 2(1), 77-99.

Scholten, PWA (2013). The multi-level governance of migrant integration: a multi-level governance perspective on Dutch migrant integration policies, In AO Korkut (Ed.), The Politics of Migration in Europe. The role of language, discourse and political parties. New York: Palgrave.

Sellers, JM, \& Lindtsröm, A. (2007). Decentralization, Local Government, and the Welfare State. Governance: An International Journal of Policy, Administration, and Institutions, 20(4), 609-632.

Soininen, M. (1992). Det kommunala flyktingmottagandet: genomförande och organisation (The municipal refugee reception: implementation and organization), Stockholm, Centrum för invandringsforskning (CEIFO).

Södergran, L. (2000). Svensk Invandrar- och Integrationspolitik: En fråga om jämlikhet, demokrati och mänskliga rättigheter [Swedish Immigration and Integration Policy: A question of equality, democracy and human rights]. Umeå: Umeå University.

Vad Jönsson, H, \& Petersen, K (2012). Denmark: A National Welfare State Meets the World. In G Brochmann \& A Hagelund (Eds), Immigration Policy and the Scandinavian Welfare State. Hampshire: Palgrave Macmillan.

Vedung, E. (1991). Utvärdering i politik och förvaltning [Evaluations in politics and administrations]. Lund: Studentlitteratur.

Vrangbk, K. (2010). Structural Reform in Denmark, 2007-09: Central Reform Processes in a Decentralised Environment. Local Government Studies, 36(2), 205-221.

Wallace Goodman, S. (2010). Integration Requirements for Integration's Sake? Identifying, Categorising and Comparing Civic Integration Policies. Journal of Ethnic and Migration Studies, 36(5), 753-772.

Wimmer, A, \& Glick-Schiller, N. (2003). Methodological nationalism, the social sciences, and the study of migration: An essay in historical epistemology. International Migration Review, 37(3), 576-610.

\section{Submit your manuscript to a SpringerOpen ${ }^{\odot}$ journal and benefit from:}

- Convenient online submission

Rigorous peer review

- Immediate publication on acceptance

- Open access: articles freely available online

- High visibility within the field

- Retaining the copyright to your article 